\title{
Introduction. Imagining Bangladesh: Contested Narratives
}

Benjamin Zeitlyn, Manpreet K. Janeja and José Mapril

\section{(2) OpenEdition}

\section{Journals}

\section{Electronic version}

URL: http://journals.openedition.org/samaj/3739

DOI: 10.4000/samaj.3739

ISSN: $1960-6060$

\section{Publisher}

Association pour la recherche sur l'Asie du Sud (ARAS)

\section{Electronic reference}

Benjamin Zeitlyn, Manpreet K. Janeja and José Mapril, «Introduction. Imagining Bangladesh: Contested Narratives », South Asia Multidisciplinary Academic Journal [Online], 9 | 2014, Online since 24 July 2014, connection on 30 April 2019. URL : http://journals.openedition.org/samaj/3739 ; DOI : 10.4000/samaj.3739

This text was automatically generated on 30 April 2019.

\section{$(1) \Theta \Theta$}

This work is licensed under a Creative Commons Attribution-NonCommercial-NoDerivatives 4.0 International License. 


\title{
Introduction. Imagining Bangladesh: Contested Narratives
}

\author{
Benjamin Zeitlyn, Manpreet K. Janeja and José Mapril
}

\section{Introduction}

1 This special issue emerges out of four years of conversations, meetings and discussions between scholars working on Bangladesh. ${ }^{1}$ These began at a workshop of the 'Bangladesh Studies Network' at the London School of Economics in June 2010. From this followed a lively Facebook group and panels at two conferences: the Association of Social Anthropologists of the UK and Commonwealth (ASA) Conference in Delhi in April 2012 and the European Association for South Asian Studies (EASAS) Conference in Lisbon in July 2012. ${ }^{2}$ Some of the papers from those panels make up this special issue.

2 The ASA conference panel in April 2012 sought to map the variegated trajectories of art and aesthetic forms (visual, literary, material, sensory, phenomenological) vis-à-vis Bangladesh, in an attempt to decentre the orientalising tropes of 'lack' through which Bangladesh is predominantly imagined in South Asia and in the 'West'. Several papers at the conference examined representations of Bangladesh through aesthetics (broadly conceived). Papers from the EASAS conference session in July 2012 focused on investigating the varying frames (developmental, aesthetic, affective, migrant, transnational) through which Bangladesh is imagined in contemporary research and popular discourses. Once again, what emerged were critical debates centred on multiple and multiplex representations and constructions of Bangladesh, debates that were generated from within Bangladesh and from Bangladeshi diaspora groups.

3 The collection of papers has evolved; it now includes a paper which looks at the relationships between art, artists and the representations of Bengali identities and Bangladesh (Selim), two papers that explore different aspects, understandings and actors of Bangladesh as a site of development (Gardner et al. and Hussain), and two papers examining the range of political positions and relations vis-à-vis Bangladesh in 
Bangladeshi diaspora groups in Lisbon and London (Mapril and Zeitlyn). The volume therefore describes contested narratives and debates on how Bangladesh is, has been, and can be imagined, drawing on visual, material, sensory, affective, and phenomenological analyses, but also includes discussions of power, development, forms of belonging/notbelonging, and connections between Bangladesh and other countries. The majority of the contributors to the special issue are anthropologists.

Our discussions started around the $40^{\text {th }}$ anniversary of Bangladesh's independence. Our special issue is a few years late to celebrate that milestone, but one must ask, is there a renewed interest in Bangladesh and if so, why? Lewis (2011: 4-6) suggests four reasons why there is renewed interest in Bangladesh, and celebrates this, claiming that Bangladesh is widely ignored in international media and academia, ${ }^{3}$ compared to the level of geopolitical interest in Pakistan and the towering presence of India in western registers of imagination.

5 Firstly, the new global concerns over energy scarcity have led to increasing attention on Bangladesh as a location for potentially valuable natural resources, including considerable reserves of natural gas, thereby changing its position in the on-going expansion and integration of the global capitalist economy.

Secondly, having long been a recipient of significant levels of development aid and having served as a testing ground for development ideas and approaches, Bangladesh's recent and rapid progress towards some of the UN Millennium Development Goals (MDGs), and the international acclaim for some of the leaders of its extensive NGO sector as 'social entrepreneurs', has lent credence to a beleaguered development industry increasingly perceived as compromised by lack of competence and wasted aid resources.

7 Thirdly, as the third most populous Muslim majority country in the world, Bangladesh has attracted attention in the post-9/11 era of the 'war on terror', gaining new strategic importance within US foreign policy. This has carried with it a counter-narrative of concern that Bangladesh's on-going governance problems could potentially encourage international terrorism and threaten its feted status as a moderate Muslim majority country. Lewis (2011: 5) notes:

(...) despite moral panics, Bangladesh continues to serve as an important antidote to Samuel Huntingdon's (1993) warning of a so-called clash of civilisations between the east and the west. It has come to be seen as an example of a moderate majority Muslim democratic country.

8 Finally, the growing global concern over the issue of climate change has positioned Bangladesh at 'the heart of a new crisis narrative that warns of 'a country underwater' and the creation of what some people have begun calling 'climate change refugees'. For the first time with climate change, Bangladesh's problems are being felt also as part of 'our' problems in the west' (Lewis 2011: 6). Bangladesh has become a key site and symbol of sea level rise and climate change adaptation. This volume of papers on contested ways of imagining Bangladesh is therefore late but still timely.

\section{Debating imaginations and identities}

9 Bangladesh's turbulent political past and present lurk in the background of all these papers, and they reflect the politically and affectively charged nature of Bangladeshi history, society, and the various manifestations of culture and identity. 

times conflicting, symbols, idioms of belonging and imaginations associated with the country. A striking example of this is the importance of Bengali and Islamic identities in the colonial and post-colonial constructions of Bangladesh, a theme approached from distinct disciplinary backgrounds such as history, anthropology and political science. Eaton (1993) described the Islamization of the region and how it became entangled with what he calls a 'frontier culture'. His objective was to show how Islam went from a 'foreign' to a 'local'/'indigeneized' religiosity and to explore the subsequent transformations such a process implied.

11 Bengalized' 'traditions' of transmission of Islamic knowledge, such as the puthis, Bengali Muslim manuscripts, crucial for the spread of religion throughout the region. These were essential for the spread of both revivalist and also what is frequently called 'syncretistic' interpretations of Islam. Roy (1983) coined the idea of an Islamic syncretistic tradition in Bengal, persuasively showing how Islam became so entangled in the region that it incorporated other religious elements-Hindu and Buddhist among others. A perfect example, according to Roy, is the cult of Pir (holy man) and their mazaars practised throughout the region (see also R. Ahmed 2001, Prasad De 1998, S. Ahmed 1996). The idea of 'syncretic' Islam in Bangladesh has been critiqued however, for its implication that there is ever, anywhere a 'pure' form of Islam that is not 'mixed' with local cultures and traditions (Gardner, 1993b).

12 This relation between Bengali and Islamic identities has also been approached as a political process that led to the independence of Bangladesh in 1971, and the subsequent changes/debates in conceptualisations of nationalism and national identity up to the present day. Several authors have focused on the emergence of Bengali secular nationalism within East Pakistan (associated with the historical formation of the Awami League). Madan (1972), for instance, soon after the independence of Bangladesh, reflected upon the historical and political processes that led to the emergence of Bengali identities to the detriment of Islam, as a key symbol for the construction of an independence political project-and how this nationalism related dialectically to the emergence of a Bangladeshi nationalism (associated with the emergence of the Bangladesh Nationalist Party) and political Islam (officially recognised with the reintegration of Jamaat-e-Islami into Bangladeshi party politics) (Jahan 2000, Choudhury 2002, Lewis 2011, van Schendel 2009 , inter alia).

13 The political scene in Bangladesh is deeply marked by the tensions over competing constructions of national identity, nationalism, memory and the past. The Liberation War is still a major theme in academic writings (see Ludden 2012) and political discourses, and punishment for crimes committed during the war continues to be a contentious issue in Bangladeshi politics. Widely accepted ideas about Bangladesh's Liberation War have been challenged in recent years by scholars such as Bose (2011). Chief among these ideas is the notion that three million Bengalis died during the war, which Bose and others cast doubt upon. Bose's analysis has been vigorously contested by scholars such as Mookerjee (2006a) and Mohaiemen (2011) who accuse her of, among other things, favouring Pakistani soldiers' testimony over Bengali witnesses and victims of the violence. Debates over 1971 and contemporary politics reveal deeply entrenched and politicised viewpoints that get to the heart of how nationalisms are nourished by histories. It is possible to see how the past and the memory are not only fields of contestation and debate but also of 
silences and forgetting (Mookherjee 2006b). Nationalism, as Renan (1992 [1882]) explained, involves shared histories as well as shared forgetting (Eriksen 1993).

Engaged in the angst and the contested histories and presents of Bengali and Bangladeshi nationalism, one risks forgetting about identities within Bangladesh that are "nonBengali'. There are non-Bengali minorities in several parts of the country, such as those who identify themselves as Chakma, Santal, Marma, Tripura, Rohingya, Garo and Bihari. Among other contributions, authors who work on these groups have shown how ethnic minorities engage with national debates about a pluralist Bangladesh and/or cultural pluralist interpretation of a Bangladeshi imagined community (see Van Schendel 2000, 2005, Bal 2007, Redclift, 2013, Abrar 2000). Considering the bloodshed over language in Bangladesh's short history, it is especially tragic and ironic that the Bangladeshi state is now considered as falling short vis-à-vis the adoption of questionable language policies of its own, when it comes to dealing with the languages and cultures of ethnic minorities (Mohsin 2003).

Other authors have researched the diverse interpretations of Islam in the region and a striking example is the extensive survey by Banu (1992) about the many faces of Islam in contemporary Bangladesh. Recent academic research has focused on the emergence of 'revivalist' or 'new' Islam in Bangladesh. Authors such as Robinson (2008) and Rozario (2006) charted the rise of revivalist Islam through practices such as wearing the burqa among Bangladeshi women, and see this as connected to multiple forms of modernity rather than 'traditional' orthodoxies. Sehhabuddin (2008), among others, illustrates how religious and secular modernities co-exist in the complex life-worlds of ordinary people, describing Muslim women who are engaged in work with secular NGOs while simultaneously investing in their religious belonging and faith.

This special issue explores these tensions and debates over identities and belonging in Bangladesh in Selim's paper. ${ }^{4}$ The author delineates the configurations of identity and representations that emerge through tracing the historical trajectories of visual art forms and practices in Bangladesh. The multiple readings of 'tradition' deployed by 'fine' artists who draw upon 'folk' and 'popular' arts, have fed into the enterprise of nation-building from the colonial past, and continue to do so in present-day post-colonial Bangladesh. The paper shows how visual arts, geopolitics, and identity formation intertwine, and emphasises both the structural constraints of visual arts in a post-colonial, developing country and the agency of artists and sculptors in challenging dominant narratives and creating 'alternative', 'de-centred' discourses of representation and belonging/notbelonging.

\section{Contested notions of home and belonging in transnational contexts}

17 'Alternative' narratives abound in Bangladesh. For every way of presenting the 'truth' there is a strongly held and often convincing counter-narrative and this is also visible in several immigration and transnational contexts. The 'Bangladeshi diaspora' includes the descendants of nineteenth century lascars recruited in Kolkata and now resident in the UK among other places (Choudury 1993, Adams 1987). Migrants who migrate to the Middle East and Malaysia, mostly for manual labour, form the most numerically significant part of the diaspora. Due to their numbers they are also the group that 
contributes most to the nation in remittances (Siddiqui 2004). In addition there are less well-known groups, contemporary probashi (emigrant) in Ryiadh, Dubai, Rome and Lisbon (Siddiqui 2004, Knights 1996, Mapril 2011), as well as many Bengalis and Bangladeshis who have migrated, permanently or temporarily, to other parts of the world. As several authors have argued (see for instance van Schendel 2009, Lewis 2011, Guhathakurta \& van Schendel 2013, inter alia), overseas migration has become integral to the very fabric of contemporary Bangladesh.

An overview of the literature on migration from Bangladesh allows us to roughly outline the existence of four types of migration: first, the Sylheti long-term migration to the United Kingdom, America, Canada and Australia (Gardner 1995, 2002, Siddiqui 2004, Rozario \& Gow 2003, Kibria 2011). This is one of the most important emigration flows in the history of Bangladesh and until the oil crisis in 1973 it was the main migration in the country (especially linking Sylhet and London, see Adams 1987, Choudury 1993, Gardner \& Shukur 1994, Gardner 1995). A second type of overseas migration is the short term, labour migration, from several regions of Bangladesh (both rural and urban), to the Middle East and Southeast Asian countries. This migration is intimately related to the oil crisis of 1973 and the development of infrastructural programmes of development in Middle Eastern countries that institutionalised labour recruitment policies, similar to the Bracero program ('manual worker' between US and México) and the Gastarbeiter ('guest worker' between Germany and Turkey), with India, Pakistan and Bangladesh (Knerr 1990). In the case of Bangladesh, these trajectories have significantly changed the migration dynamics in the country. It was in this context that other countries carried out similar programmes of recruitment of Bangladeshi workers such as South Korea, Malaysia and Thailand, among others.

19 A third type of migration is the cross border land routes between Bangladesh and India, usually used by poor rural populations that either migrate for work in large Indian cities, such as Mumbai, Delhi or Kolkata, or work in industries or mining companies in Indian territory (see Gardner 2012, Hussain 2013). This migration route is considered 'illegal' by the Indian authorities and has stirred up several clashes between the Bangladeshi and Indian governments (see Samaddar 1999, Chatterji 1999, Rahman \& van Schendel 2003, Ramachandran 2003), and generated tensions between the Indian Central and State (West Bengali) governments (Chatterji 2007). Finally, a fourth type of migration has as its destinations several Southern European countries. This is a migratory flow that began in the late 1980s and has grown significantly in the last few decades to countries such as Italy, Spain, Portugal, Greece and Cyprus. ${ }^{5}$ This is a migration flow that mainly includes young middle class people, urbanised and educated (Knights 1996, Zeitlyn 2006, Mapril 2007, Mapril 2014). Thus, international migration has become an important part of the contemporary Bangladeshi landscape and this is visible in distinct areas of social life, ranging from politics and economics to culture and media.

These migration and diaspora phenomena have been researched from distinct perspectives and the literature can be organized into two main strands. Firstly, several authors have researched the impact of international migration on Bangladesh, either focusing on financial remittances and economic development or on social remittances, religion and gender. The second strand looks at migration as a local and transnational experience, focusing on immigrants in the receiving contexts and exploring the changing links with Bangladesh. 
21 Some examples of the first are Gardner's work (1993a, 1995, 2002, 2008), as well as that by Siddiqui (2001) and Callan (2012). Gardner (1995) explores the impact of Londonis in Sylhet and the UK. She vividly shows how the transformation of economic and social relations in Sylhet due to the extensive migration to the UK, was manifested not only in the landscape itself (the building of pucca houses), but also in kinship and gender relations, the management of the household and conceptions of Islam. Siddiqui (2001), on the other hand, focuses on another dimension of these transformations, namely the relation between labour migration and women in contemporary Bangladesh. Her objective has been to show how the transformation of migration dynamics in Bangladesh, associated with the restructuring of the global economy, was accompanied by the feminisation of overseas migration, especially to Middle Eastern and Southeast Asian countries. More recently, Callan (2012) has shown how the integration of Sylhet in the global economy, through overseas migration, has transformed marriage patterns, which in turn, have had a deep impact on the health conditions of those involved.

The other strand of studies on Bangladeshi migration and diasporas focuses on the study of transnational migration per se and the relations of Bangladeshis and their children with contexts of immigration in places such as the UK, USA, Italy, Spain and Portugal, among others. One of the pioneers in these studies is John Eade, who in 1989, published The Politics of Community: The Bangladeshi Community in East London. His objective was to show how Bangladeshis were increasingly engaged in British local and national, mainstream, political activities. Eade and Garbin (2002) have also researched the emergence of 'Banglatown' in the East End of London in the context of the production of London as a global city. Kibria (2011) and Sultana (2009) have both explored the presence of Bangladeshis in the USA and Malaysia, respectively. Focusing on the fourth type of migration we identify, other researchers have shown the complexities of Bangladeshi contemporary immigration flows by researching lesser-known Bangladeshi communities in countries such as Italy (Knights 1996), Spain (Zeitlyn 2006) and Portugal (Mapril 2007, 2011, 2014).

Another avenue of research explores the intergenerational changes in the practices and perceptions of religion between parents and their children (Glynn 2002, Kibria 2008, De Hanas 2013, Rozario 2011, Zeitlyn 2012, 2013, inter alia). Glynn (2002), for instance, showed how forms of 'revivalist' Islam, with a transnational perspective, are increasingly appealing to young British Bengali Muslims and how these ideological choices are drawing them away from their parents' conceptions of Islam (which are often described as being more 'Bengali', 'sufi' and 'syncretic'). Kibria (2008) compared young British and US Bangladeshis and revealed how the growth of what some authors refer to as 'revivalist' Islam, and Kibria calls the 'new Islam', is seen as an answer to the increasing visibility and salience of Muslim identities, a sense of political and cultural alienation, and also a way of distancing themselves from Bangladeshi identities. Kibria noted that the generational aspect of adherence to forms of revivalist Islam is more marked and institutionalised in the UK than it is in the US.

Within these studies on immigrant Bangladeshis and their children, it is essential to mention the importance of studies that focus on the relation between transnationalism and the imaginations of home. Gardner (2002), for instance, showed how ageing among Sylheti elders in the UK revealed the complexities about the making of notions of home and belonging. Images of home and away-desh and bidesh (Gardner 1993a)-are continuously used by these elders to think about their place of belonging. Garbin (2004), 
on the other hand, explored the ways Sylheti and British Bangladeshis built transnational social spaces between the UK and Sylhet. His work focuses not only on the making of transnational kinship groups but also on the ways these translocal social fields allow the circulation of several forms of capital that are used differently according to context. Zeitlyn (2013) has shown how these transnational social spaces change and collapse notions of desh and bidesh and the discourses once associated with them, due to intensified global connections, communications and mobility. Zeitlyn (2012, 2013) explores the ways British Bangladeshi children learn notions of home and belonging between Bangladesh and the UK. He argues that the British Bangladeshi transnational social field, a transnational social space in which British Bangladeshis exchange and compete over different forms of capital and meaning, disrupts notions of desh and bidesh (Zeitlyn 2012).

Transnational family life, the making of kinship and the arrangement of marriages, are also areas of research by authors such as Gardner $(1995,2012)$, Pollen (2002) and Khanum (2000), to mention just a few examples. Marriage migration is now one of the principal flows of people between Bangladesh and the UK, contributing to about a quarter of the increase in the British Bangladeshi population between 2001 and 2011 (Zeitlyn 2013). Marriage is of course much more than a migration flow, cementing transnational relationships and exchanges for another generation.

Another dimension to these transnational studies of Bangladeshi immigration is the study of transnational political processes, such as homeland politics. Glynn (2006) presented a fascinating history of the role of East Pakistani Bengalis in the UK and their support for the Bangladeshi independence war. Alexander (2013) showed how British Bangladeshi secularists and Islamists, struggle for a normative representation of Bangladesh and how this relates to the racialisation of Bangladeshis in UK citizenship regimes. Eade (1996) and Eade and Garbin (2002) also focused on contemporary transnational political activism, the manipulation of Bengali cultural symbols, such as the Boishaki mela, and the making of a (urban and political) place for British-Bangladeshis in London. This literature on transnational political activism unpacks the contested nature of the ways in which Bangladesh is imagined by its expatriates and their descendants and is an area that this special issue will further contribute to, with papers by Zeitlyn and Mapril.

Zeitlyn draws upon discussions about the International Crimes Tribunal (set up to try alleged war criminals from the Liberation War in 1971) as well as recent associated protests at Shahbagh and by the Hefazot-e-Islami movement to identify competing discourses about Bangladesh, in accounts of events from and by British Bangladeshis in London. Through an analysis of transnational and on-line political engagement, the paper identifies ways in which dominant discourses about Bangladesh are actively contested and resisted by diaspora communities and alternative discourses created. Competing and contentious diasporic narratives of 'critical events' (Das 1995) also emerge in Mapril's description of the Language Day (Ekushey / 21 February) celebrations in Lisbon. Through a contextual analysis of the celebrations, the paper broadens out to examine the fraught and fractional nature of the emergence of a Bangladeshi 'community' and a Bangladeshi diasporic public sphere in Lisbon, in dialogue with various local, national and transnational formations. As we have seen in the previous section, contested narratives of these critical events cut to the heart of Bangladeshi politics and the story of its independence in 1971. 


\section{Development and the politics machine} inaccurate, but as Hassan points out, this is only one side of the 'Bangladesh paradox'. It is the side of the paradox that has made Bangladesh synonymous with corruption and mismanagement. It is this side which is most often seen and commented upon by a wide range of people with vested interests in Bangladesh. Since Henry Kissinger famously called Bangladesh a 'basket case', in a discussion about foreign policy, just as the country became independent against his wishes in 1971, hostile foreign observers have regularly seen only one side of the Bangladesh paradox. Their vision clouded by local or global politics, they only see the side of Bangladesh that they do not like. This is the 'Kissinger myopia'.

Recent examples of 'Kissinger myopia' include Cadman (2013), Hazra (2013) and Bhuyia (2013). Cadman, a British barrister representing members of Jamaat-e-Islami who are the accused in the ICT, described the situation in Bangladesh as 'descending rapidly into civil war'. Hazra (2013), writing in the Indian press, also described Bangladesh as being in a state of civil war, placing the blame firmly on the Jamaat-e-Islami and its student wing, Islami Chhatra Shibir. Bhuyia (2013), writing for the Islamic news website OnIslam, also described Bangladesh as being in a civil war, but this time blamed the 'fascist' 
government and the ICT. What is interesting about these three recent examples of 'Kissinger myopia' is that their authors represent western, Indian and Islamist positions, ones whose interference in Bangladesh are regularly cited in competing narratives to be the source of everything that is wrong with Bangladesh. While there is a lot wrong in Bangladesh, there is also a lot to celebrate. The apparently chaotic nature of Bangladesh conceals some of the progress. 'Kissinger myopia' leads to what are often rather unnecessarily negative portrayals of Bangladesh, ones that can become self-fulfilling prophecies.

Such understandings of Bangladesh have been partly responsible for the rise of NGOs funded by foreign donors, which Hussain discusses in this volume. NGOs have been considered more effective, efficient and less corrupt by donors than the state. Their rise to prominence in Bangladesh is seen as a crucial factor in what is going right in Bangladesh by analysts such as The Economist (2012), who describe NGOs such as BRAC as the 'magic ingredient' in Bangladesh's recent development success. Anthropologists such as Gardner et al. and Hussain, conducting ethnographic fieldwork among poor people in Bangladesh often have a different, emic perspective from the economists. Hussain's paper in this volume, drawing on the notion of governmentality, unpicks the rather simplified and binary way the state and civil society are conceptualised and illustrates how they act in practice in Bangladesh. He reveals the complex layers of non-state organisations, at local, national and transnational levels that act in collaboration, competition or contradiction with the state, producing 'state-like effects'. NGOs are manifestations of soft power interventions in Bangladesh, beholden to international as well as local agendas. The Bangladesh paradox does not only have two sides, but multiple layers, actors and scales.

Gardner et al.'s paper investigates the complex and messy array of discourses, dreams, actors and corporate Public Relations that the concept of development (unnoti) conjures up in Bangladesh, specifically in the context of the Bibiyana Gas Field in Sylhet. The authors explore how notions of development connect with competing ways of understanding Bangladesh, critiquing it and dreaming of what it might become. The notion of development is one where there is no common understanding about either the intended end goal or the right path. Agendas and strategies at international, national and local scales and within political, corporate and family structures intersect with 'development' to produce a diverse array of discourses and outcomes. Hussain and Gardner et al.'s accounts indicate that a range of development actors fill the spaces in and around the 'poor governance' in Bangladesh with competing interests and often wildly different ways of operating.

Despite widespread critiques, governance in Bangladesh is not all bad. The World Bank (2007) outlines the following five areas in which governance in Bangladesh has been relatively successful. The state has created the space for a dynamic private sector (although The Economist (2012) characterises the private sector in Bangladesh as 'stunted'). Successive Bangladeshi governments have encouraged labour migration and encouraged remittances and investments, which the World Bank sees as a successful economic strategy. According to Lewis (2011: 152), remittances help to '(...) counteract regular deficits in other areas of the economy such as trade, services and other income'. Official figures from the Bangladesh Central Bank indicate that remittances, through formal channels, were 500,000 US dollars in 1985 while in 2007, they reached 7 billion US dollars (Lewis 2011; see also Van Schendel 2009 which with different figures, reveals a 
similar trend). Most of these overseas remittances come from the Middle East, and the largest single national source is Saudi Arabia, but significant flows also come from the US and the United Kingdom (Lewis 2011). According to data from the Bangladesh Bank, remittance income accounted for about $12 \%$ of Bangladesh's GDP in most recent years.

Furthermore, according to the World Bank (2007), successive Bangladeshi governments have been relatively good at making pro-poor expenditure choices and keeping military spending low. The state has also formed effective partnerships with NGOs and the private sector to deliver services. Gardner et al. and Hussain subject these 'partnerships' to a critical examination in their papers in this volume. Finally, the state has greatly increased its capacity to manage natural disasters (World Bank 2007). However, recent industrial disasters in the garments industry in the Tazreen fire and Rana Plaza collapse suggest that although Bangladeshi governments may have increased their capacity to cope with natural disasters, further work needs to be done in the area of effective workplace safety and regulation. Bangladesh's position as the cheapest place to make clothes relies on hazardous workplace conditions for its (mostly female) garment workers, suppression of labour movements and human rights abuses.

Human rights is an area where concerns about governance in Bangladesh push the country firmly back into Kissinger territory. Extrajudicial executions, torture and impunity for members of the security forces have long been problems in Bangladesh under both major democratic parties, as well as military governments (HRW 2012). These problems become politicised when the security forces and judiciary are used to suppress opposition from rival parties and the press. Of course, when the security forces and judiciary act for the benefit of the nation and when they act for politically vested interests is an intensely debated matter. Perspectives on the International Criminal Tribunal, Shahbagh and the events at Shapla Chottor on the 5th and 6th of May 2013, as discussed by Zeitlyn, illustrate this. Some regard the ICT as the last part of the unfinished revolution of 1971, important for closure of the wounds of the Liberation War. To others though, the tribunal is a sham, an act of political vengeance to destroy the political opposition to the ruling Awami League government.

Concerns about human rights in the country remain pertinent and contested. The government has targeted prominent figures from civil society such as Muhammad Yunus (founder of the Grameen Bank, an influential microfinance initiative which provides small loans to poor people who do not qualify for conventional bank loans due to lack of/ inadequate collateral) and Adilur Rahman (secretary advocate of Odhikar, a human rights $\mathrm{NGO}$ ) for persecution in the press, courts and by law enforcement agencies. Is Yunus a worthy Nobel Prize winner, an iconic symbol of Bangladeshi innovation in the face of poverty, or a corrupt predatory capitalist? Is Rahman a brave defender of human rights in Bangladesh, persecuted for publishing 'inconvenient truths', or an opposition stooge making life difficult for the government? Recent elections in Bangladesh saw tensions running high, violent demonstrations and state repression of opposition groups and attacks against the press. In the absence of a trusted media and judiciary, contested and competing narratives proliferate. 'The truth' becomes ever murkier.

\section{Contested narratives}

This collection of papers touches on many of the key issues in contemporary Bangladesh, often approaching them from the margins, or through an examination of seemingly 
mundane practices, people, places, and artefacts. As Lewis (2011) argues, Bangladesh itself is in many ways a marginal place, but it is one whose stock is rising. This is not a collection of papers that portrays Bangladesh as a poor, hopeless 'basket case' in need of development, or just a test case of various development initiatives. The diversity, complexity, agency, creativity and determination of Bangladeshis emerge here. The papers in this special issue contain a set of challenges, from the authors and many of the people they spoke to in the course of their research, to received wisdom on Bangladesh. These papers reveal some of the key debates within Bangladeshi society and politics, and the ways in which Bangladesh is perceived, represented and related to the rest of the world. The messages that emerge are not clear or simple: this is a complicated and contested country, one that is changing rapidly and confounding predictions from all sides.

\section{BIBLIOGRAPHY}

Abrar, Chowdhury (ed.) (2000) On the Margin: Refugees, Migrants and Minorities, Dhaka: RMMRU.

Adams, Caroline (1987) Across Seven Seas and Thirteen Rivers: Life Stories of Pioneer Sylheti Settlers in Britain, London: THAP Books.

Ahmed, Rafiuddin (1981) The Bengal Muslims 1871-1906: A Quest for Identity, New Delhi: Oxford University Press.

Ahmed, Rafiuddin (ed.) (2001) Understanding the Bengal Muslims: Interpretative Essays, New Delhi: Oxford University Press.

Ahmed, Sufia (1996) Muslim Community in Bengal 1884-1912, Dhaka: UPL Press.

Alexander, Claire (2013) 'Contested Memories: The Shahid Minar and the Struggle for Diasporic Space', Ethnic and Racial Studies, 36(4), pp. 590-610.

Bal, Ellen (2007) They Ask if We Eat Frogs: Garo Ethnicity in Bangladesh, Singapore: ISEAS Publishing. Banu, Razia (1992) Islam in Bangladesh, Leiden: Brill Publishers.

Bhuyia, Ferdous Ahmad (2013) 'Trials lead Bangladesh to Civil War', OnIslam, $18^{\text {th }}$ March, 2013, http://www.onislam.net/english/news/asia-pacific/461855-trials-lead-bangladesh-to-civilwar.html (accessed August 2013).

Bose, Sarmila (2011) Dead Reckoning: Memories of the 1971 Bangladesh War, Chichester: Columbia University Press.

Cadman, Toby (2013) Bangladesh Justice: Damned if You Do, Damned if You Don't, Open Democracy, http://www.opendemocracy.net/opensecurity/toby-m-cadman/bangladesh-justice-damned-ifyou-do-damned-if-you-dont (accessed 3 March 2014).

Callan, Allyson (2012) Patients and Agents: Mental Illness, Modernity and Islam in Sylhet, Bangladesh, Oxford: Berghahn.

Chatterji, Joya (1999) 'The Fashioning of a frontier: The Radcliffe Line and Bengal's Border Landscape, 1947-52', Modern Asian Studies, 33(1), pp. 185-242. 
Chatterji, Joya (2007) 'Dispersal' and the Failure of Rehabilitation: Refugee Camp-Dwellers and Squatters in West Bengal', Modern Asian Studies, 41(5), pp. 997-1007.

Choudhury, Serajul (2002) Middle Class and Social Revolution in Bengal: An Incomplete Agenda, Dhaka: UPL Press.

Choudhury, Youssuf (1993) The Roots and Tales of the Bangladeshi Settlers, Birmingham: Sylheti Social History Group.

Das, Veena (1995) Critical Events: An Anthropological Perspective on Contemporary India, New Delhi: Oxford University Press.

DeHanas, Daniel Nilsson (2013) 'Elastic Orthodoxy: The Tactics of Young Muslim Identity in the East End of London.' in Nathal Dessing, Nadia Jeldtoft, Jorgen Nielson \& Linda Woodhead (eds.), Everyday Lived Islam in Europe, Farnham: Ashgate, pp. 82-97.

Drèze, Jean; Sen, Amartya (2013) An Uncertain Glory: India and its Contradictions, Princeton: Princeton University Press.

Eade, John (1989) The Politics of Community, London: Avebury.

Eade, John (1996) 'Nationalism, Community and the Islamization of Space in London', in Barbara Metcalf (ed.), Making Muslim Space in North America and Europe, Berkeley, CA: University of California Press, pp. 217-33.

Eade, John; Garbin, David (2002) 'Changing Narratives of Violence, Struggle and Resistance: Bangladeshis and the Competition for Resources in the Global City', Oxford Development Studies, 30(2), pp. 137-51.

Eaton, Richard (1993) The Rise of Islam and the Bengal Frontier, Berkeley: University of California Press.

Eriksen, Thomas Hylland (1993) Ethnicity and Nationalism, Anthropological Perspectives, London: Pluto Press.

Garbin, David (2004) Migrations, Territoires Diasporiques et Politiques Identitaires: Bengalis Musulmans entre ‘Banglatown' et Sylhet, $\mathrm{PhD}$ thesis, Tours: Université François Rabelais. Gardner, Katy (1993a) ‘Desh bidesh: Sylheti Images of Home and Away’. Man, 28(1), pp. 1-15. Gardner, Katy (1993b) 'Mullahs, Migrants, Miracles: Travel and Transformation in Sylhet'. Contributions to Indian Sociology, 27(2), pp. 213-235.

Gardner, Katy; Sukur, Abdus (1994) “I'm Bengali, I'm Asian and I'm living here': the Changing Identity of British Bengalis', in Roger Ballard (ed.), Desh Pardesh: The South Asian Presence in Britain, New Delhi: B.R. Publishing Corporation, pp. 142-64.

Gardner, Katy (1995) Global Migrants, Local Lives: Travel and Transformation in Rural Bangladesh, Oxford: Oxford University Press.

Gardner, Katy (2002) Age, Narrative and Migration: The Life Course and Life Histories of Bengali Elders in London, London: Berg Publishers.

Gardner, Katy (2012) Discordant Development: Global Capitalism and the Struggle for Connection in Bangladesh, London: Pluto Press.

Glynn, Sarah (2002) 'Bengali Muslims: the New East End Radicals’, Ethnic and Racial Studies, 25(6), pp. 969-88.

Glynn, Sarah (2006) 'The Spirit of 71: How the Bangladeshi War of Independence has Haunted Tower Hamlets', Socialist History Journal, 29, pp. 56-75. 
Guha, Ramachandra (2012) 'The Two Bengals-West Bengal can now learn a few things from Bangladesh', The Telegraph, Calcutta, 30 June 2012.

Guhathakurta, Meghna; Van Schendel, Willem (eds.) (2013) The Bangladesh Reader: History, Culture and Politics, Durham: Duke University Press.

Hassan, Mirza (2013) 'Political Settlement Dynamics in a Limited-access Order: The Case of Bangladesh', ESID Working Paper No. 23, Manchester: Effective States and Inclusive Development Research Centre (ESID) School of Environment and Development, The University of Manchester.

Hazra, Indrajit (2013) “Civil War' Erupts in Bangladesh; 4 Killed', Hindustan Times, 22 February.

Human Rights Watch (HRW) (2012) World Report 2012: Bangladesh, New York: Human Rights Watch, http://www.hrw.org/world-report-2012/world-report-2012-bangladesh.

Hussain, Delwar (2013) Boundaries Undermined: The Ruins of Progress on the Bangladesh-India Border, London: Hurst and Co.

Jahan, Rounaq (ed.) (2000) Bangladesh: Promise and Performance, Dhaka, UPL Press.

Janeja, Manpreet Kaur (2010) Transactions in Taste: The Collaborative Lives of Everyday Bengali Food, London: Routledge.

Kabeer, Naila (2000) The Power to Choose: Bangladeshi Women and Labour Market Decisions in London and Dhaka, London: Verso.

Khanum, Sultana Mustafa (2000) 'Habitus and its Implications in Constructing Kinship Ties: Data from a Bangladeshi Settlement in Britain', in Monika Böck \& Aparna Rao (eds.), Culture, Creation and Procreation: Concepts of Kinship in South Asian Practice, London: Berghahn Books, pp. 199-218.

Kibria, Nazli (2008) 'The 'New Islam' and the Bangladeshi Youth in Britain and the USA', Ethnic and Racial Studies, 31(2), pp. 243-66.

Kibria, Nazli (2011) Muslims in Motion: Islam and National Identity in the Bangladeshi Diaspora, New Brunswick: Rutgers University Press.

Knerr, Beatrice (1990) 'South Asian Countries as Competitors on the World Labour Market', in Colin Clarke, Ceri Peach \& Steven Vertovec (eds.), South Asians Overseas: Migration and Ethnicity, Cambridge: Cambridge University Press, pp. 173-96.

Knights, Melanie (1996) 'Bangladeshi Immigrants in Italy: from Geopolitics to Micropolitics', Transactions of the Institute of British Geographers, New Series, 21(1), pp. 105-23

Lewis, David (2011) Bangladesh: Politics, Economy, and Civil Society, Cambridge: Cambridge University Press.

Ludden, David (2011) 'The Politics of Independence in Bangladesh', Economic and Political Weekly, 46(35), pp. 79-85.

Madan, Triloki Nath (1972) 'Two Faces of Bengali Ethnicity: Muslim Bengali or Bengali Muslim', The Developing Economies, 10(1), pp. 74-85.

Mapril, José (2007) ‘The 'New’ South Asians: the Political Economy of Migrations Between Bangladesh and Portugal', Oriente, 17, pp. 81-99.

Mapril, José (2011) 'The Patron and the Madman: Migration, Success and the (In)visibility of Failure Among Bangladeshis in Portugal', Social Anthropology, 19(3), pp. 288-96.

Mapril, José (2014) 'The Dreams of Middle Class: Consumption, Life-course and Migration Between Bangladesh and Portugal', Modern Asian Studies, 48(3), pp. 693-719. 
Mohsin, A. (2003) 'Language, Identity, and the State in Bangladesh', in M. Brown \& S. Ganguly (eds.), Fighting Words: Language Policy and Ethnic Relations in Asia, Cambridge, MA: MIT Press, pp. 81-103.

Mookherjee, Nayanika (2006a) ‘Bangladesh War of 1971: A Prescription for Reconciliation?', Economic and Political Weekly, 41(36), pp. 3901-3.

Mookherjee, Nayanika (2006b) “Remembering to Forget': Public Secrecy and Memory of Sexual Violence in the Bangladesh War of 1971', Journal of the Royal Anthropological Institute, 12(2), pp. 433-50.

Mohaiemen, Naeem (2011) 'Flying Blind: Waiting for a Real Reckoning on 1971', Economic and Political Weekly, 46(36), pp. 40-52.

O’Neill, Jim; Wilson, Domini; Purushothaman, Roopa; Stupnytska, Anna (2005) 'How Solid are the BRICs?', Global Economics Paper No: 134, New York: Goldman Sachs, http:// www.goldmansachs.com/our-thinking/archive/archive-pdfs/how-solid.pdf (accessed 6 August 2013).

Pollen, Roseanna (2002) Bangladeshi Family Life in Bethnal Green, PhD dissertation, London: Department of Social Anthropology, London School of Economics.

Prasad De, Dhurjati (1998) Bengal Muslims in Search of Social Identity, 1905-1947, Dhaka: UPL Press. Rahman, Mahbubar; Van Schendel, Willem (2003) 'I am not a Refugee: Rethinking Partition Migration', Modern Asian Studies, 37(3), pp. 551-84.

Ramachandran, Sujata (2003) “Operation Pushback': Sangh Parivar, State, Slums and Surreptitious Bangladeshis in New Delhi', Economic and Political Weekly, 38(7), pp. 641-42.

Redclift, Victoria (2013) Statelessness and Citizenship: Camps and the Creation of Political Space, Abingdon: Routledge.

Renan, Ernest (1992) Qu'est-ce qu'une nation?, Paris: Presses Rocket, [1882].

Robinson, Francis (2008). 'Islamic Reform and Modernities in South Asia', Modern Asian Studies, 42 (2-3), pp. 259-81.

Rozario, Santi; John Gow (2003) 'Bangladesh: Return Migration and Social Transformation', in Robyn Iredale, Fei Guo \& Santi Rozario (eds.), Return Migration in the Asia Pacific, Cheltenham: Edward Elgar, pp. 47-87.

Rozario, Santi (2006) ‘The New Burqa in Bangladesh: Empowerment or Violation of Women's Rights?', Women's Studies International Forum, 29, pp. 368-80.

Rozario, Santi (2011) 'Islamic Piety Against the Family: from 'Traditional' to 'Pure' Islam', Contemporary Islam, 5(3), pp. 285-308

Roy, Asim (1983) The Islamic Syncretistic Tradition in Bengal, New Delhi: Sterling Publishers.

Samaddar, Ranabir (1999) The Marginal Nation: Transborder Migration from Bangladesh to West Bengal, New Delhi: Sage Publications.

Sehhabuddin, Elora (2008) Reshaping the Holy: Democracy, Development and Muslim Women in Bangladesh, New York: Columbia University Press.

Siddiqui, Tasneem (2001) Transcending Boundaries: Labour Migration of Women from Bangladesh, Dhaka: University Press Limited.

Siddiqui, Tasneem (2004) Institutionalising Diaspora Linkage: The Emigrant Bangladeshi in UK and USA, Dhaka: International Organisation for Migration. 
Nayeem, Sultana (2009) The Bangladeshi Diaspora in Malaysia: Organizational Structure, Survival Strategies and Networks, Münster: LitVerlag.

The Economist. 2012. 'Bangladesh and Development: The Path through the Fields', 3 November. van Schendel, Willem (2000) 'Bengalis, Bangladeshis and Others: Chakma Visions of a Pluralist Bangladesh', in Rounaq Jahan (ed.), Bangladesh: Promise and Performance, Dhaka: UPL Press, pp. 65-106.

van Schendel, Willem (2005) The Bengal Borderland: Beyond State and Nation in South Asia, London: Anthem Press.

van Schendel, Willem (2009) A History of Bangladesh, Cambridge: Cambridge University Press.

World Bank (2007) 'Chapter 7: Governance and Growth: the Bangladesh Conundrum', in 'Bangladesh strategy for sustained growth', Bangladesh Development Series, Paper No. 18, The World Bank Office, Dhaka.

World Bank (2013) ‘World Development Report: Jobs', Washington DC.

Zeitlyn, Benjamin (2006) Migration from Bangladesh to Italy and Spain, Dhaka: R.M.M.R.U.

Zeitlyn, Benjamin (2012) 'Maintaining Transnational Social Fields: The Role of Visits to Bangladesh for British Bangladeshi Children', Journal of Ethnic and Migration Studies, 38(6), pp. 953-68.

Zeitlyn, Benjamin (2013) ‘Desh Bidesh Revisited’, Identities, 20(3), pp. 253-69.

\section{NOTES}

1. Many people contributed to this special issue in different ways. We would like to thank the authors of articles in the issue for their hard work, as well as the participants in four forums for their critical comments and feedback. The special issue emerged from discussions at the Bangladesh Studies Network meeting at the London School of Economics in June 2010. We would like to thank David Lewis, Delwar Hussain, Hannah Jennings, and other participants for organising the meeting as well as their inspiration and encouragement. A panel on Bangladesh at the ASA conference in New Delhi in April 2012 contributed to the special issue, and we would like to thank the participants, and the panel discussant Nayanika Mookherjee for her feedback. At the EASAS conference in Lisbon in July 2012 another panel on Bangladesh fed into the special issue, and we would like to thank Fabiene Gama, Ellen Bal and others for their comments and discussions. There were further productive engagements at the Brick Lane Circle's third annual conference on Bangladesh in London in April 2013, and we would like to thank the participants, and Muhammad Ahmedullah for organising the event. Finally we would like to thank Roger Jeffery, the editors of SAMAJ, and anonymous peer reviewers for their thorough and patient editing and reviewing.

2. Nayanika Mookherjee also played a key role in bringing together these panels.

3. At the 2012 EASAS conference, for instance, there were only seven papers on Bangladesh, among approximately 300 papers on South Asia.

4. Two other papers-on food and subjectivities (Janeja) and contentious photographic representations of Bangladesh (Gama)-could not be included due to time constraints. For a discussion of the disputed emergent definitions of normal Bangladeshi Bengali food vis-à-vis West Bengali food, entangled in the historical biography of the region, as a register that reveals myriad contested narratives of imagining Bangladesh, see Janeja (2010). Gama's paper was part of a comparative study on representations of Bangladesh and Brazil by photographers with a 
heightened sense of the ways in which the 'majority world' (where most of the world's inhabitants live) is represented in western dominated media and visual arts. Photographers at the Pathshala Academy in Dhaka, determined to resist the predominantly negative portrayals of Bangladesh and other developing countries, set about explicitly creating 'alternative' representations and narratives about the country.

5. In spite of being understudied, it is also important to mention the presence of probashis in France, Germany, Belgium and Switzerland, to mention just a few.

\section{ABSTRACTS}

Bangladesh is a country that appears only on the margins of western news and academic interest. When it does, it is usually in the context of catastrophes. In this Introduction to the special issue, we agree with Lewis (2011) that this large, complex and dynamic country merits more attention. Looking at it through the lens of 'contested narratives' centring on identities, notions of home and belonging in transnational Bangladeshi communities and the development, economy and politics of the country, we identify areas in which these contested narratives are particularly pertinent to current events in Bangladesh and which the papers in this special issue touch upon.

\section{AUTHORS}

\section{BENJAMIN ZEITLYN}

Lecturer in International Education and Development, Centre for International Education, University of Sussex, Brighton, UK

\section{MANPREET K. JANEJA}

Assistant Professor, Centre for South Asia, Department of Cross-Cultural and Regional Studies, University of Copenhagen, Denmark

\section{JOSÉ MAPRIL}

Research fellow, Centre for Research in Anthropology, New University of Lisbon 